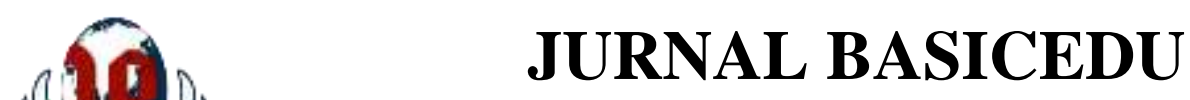

Volume 5 Nomor 4 Tahun 2021 Halaman 1809 - 1818

Research \& Learning in Elementary Education

https://jbasic.org/index.php/basicedu

PAHLATAM

\title{
Peningkatan Pembelajaran Pendidikan Agama Islam Melalui Model PAIKEM Bagi Siswa Sekolah Dasar
}

\author{
Repelita $^{凶}$ \\ Sekolah Dasar Negeri 07 Pasaman, Indonesia \\ E-mail: repelitazul@gmail.com
}

\begin{abstract}
Abstrak
Pengamatan dilakukan pada kelas V SDN 07 Pasaman dengan tujuan untuk melihat efek menggunaan model PAIKEM terhadap Pembelajaran Pendidikan Agama Islam. Karena masih banyak proses pembelajaran Pendidikan Agama Islam yang dilakukan hanya dengan memakai metoda tanya jawab dan ceramah. Sehingga proses pembelajaran belum seperti yang diharapkan. Penelitian ini menggunakan pendekatan kualitatif dan kuantitatif. Proses pembelajaran terdiri atas tiga kegiatan yaitu: (1) Kegiatan awal, (2) Kegiatan inti (3) kegiatan akhir. Untuk mengetahui peningkatan hasil pembelajaran Pendidikan Agama Islam melalui model PAIKEM digunakan data yang berkaitan dengan aktivitas siswa dan aktivitas guru, serta pencapaian peningkatan pembelajaran siswa itu sendiri. Hasil analisis pada siklus 1 dan siklus 2, dapat digambarkan peningkatan hasil proses belajar mengajar dengan menggunakan model PAIKEM. Siswa lebih percaya diri dan berani tampil untuk menunjukkan kemampuannya. Siswa lebih bersemangat dan termotivasi belajar dalam situasi yang menyenangkan. Untuk hal ini, guru dituntut mengubah peran dan fungsinya menjadi fasilitator, mediator, mitra belajar anak didik, dan evaluator.
\end{abstract}

Kata kunci : Pembelajaran, Model PAIKEM

Abstract

Observations were made in grade V SDN 07 Pasaman to see the effect of using the PAIKEM model on Islamic Religious Education Learning. Because there are still many learning processes of Islamic Religious Education that are carried out only by using the question and answer method and lectures so that the learning process is not as expected. This research uses qualitative and quantitative approaches. The learning process consists of three activities, namely: (1) initial activities, (2) core activities (3) final activities. To determine the increase in learning outcomes of Islamic Religious Education through the PAIKEM model, data related to student activities and teacher activities are used, as well as the achievement of increasing student learning itself. The results of the analysis in cycle 1 and cycle 2 can be described as an increase in the results of the teaching and learning process using the PAIKEM model. Students are more confident and dare to appear to show their abilities. Students are more enthusiastic and motivated to learn in pleasant situations. For this, teachers are required to change their roles and functions to become facilitators, mediators, student learning partners, and evaluators.

Keywords: Learning, PAIKEM Model

Copyright (c) 2021 Repelita

Corresponding author :

Email:repelitazul@gmail.com

DOI : https://doi.org/10.31004/basicedu.v5i4.989

ISSN 2580-3735 (Media Cetak)

ISSN 2580-1147 (Media Online)

Jurnal Basicedu Vol 5 No 4 Tahun 2021

p-ISSN 2580-3735 e-ISSN 2580-1147 


\section{PENDAHULUAN}

Untuk mengoptimalkan proses pembelajaran PAI di sekolah dasar, guru harus berusaha menyajikan PAI sebaik mungkin sesuai dengan kompetensi yang telah ditetapkan. Guru harus menentukan dan memilih strategi, metode dan teknik yang sesuai agar dapat melibatkan siswa secara aktif dalam pembelajaran, sehingga pembelajaran dapat berlangsung dengan baik dan menarik bagi siswa. Cara dan usaha yang dilakukan pendidik untuk mencapai tujuan pembelajaran merupakan suatu kewajiban yang harus dilakukan untuk mencapai hasil belajar yang diharapkan. Pengertian tentang hasil belajar menurut Nawawi (Susanto, 2014, p. 5) menyatakan hasil belajar dapat diartikan sebagai tingkat keberhasilan siswa dalam mempelajari materi pelajaran di sekolah yang dinyatakan dalam skor yang diperoleh dari hasil tes mengenal sejumlah materi pelajaran tertentu. (Sudjana, 1992, p. 34) mengemukakan bahwa hasil belajar adalah kemampuan yang dimiliki oleh siswa setelah ia menerima pengalaman belajar. Sedangkan menurut Keller (Mulyono, 2003), hasil belajar adalah perbuatan yang terarah pada penyelesaian tugas-tugas belajar. Dengan demikian, hasil belajar merupakan kemampuan yang diperoleh siswa setelah mengikuti proses pembelajaran baik berbentuk pengetahuan, sikap maupun keterampilan.

(Saepul Rahmat, 2015) menyatakan metode pembelajaran merupakan salah satu penentu hasil belajar siswa serta bertujuan untuk meningkatkan kualitas proses pembelajaran menjadi pembelajaran yang aktif, efektif dan efisien. (Uno, 2012, p. 7) mendefinisikan metode pembelajaran sebagai cara yang digunakan guru dalam menjalankan fungsinya dan merupakan alat untuk mencapai tujuan pembelajaran. (Surakhmad, 1990) mengemukakan, bahwa dalam menggunakan metode pembelajaran di sekolah, seorang guru dapat menggunakan metode pembelajara yang berbeda-beda antara kelas yang satu dengan kelas yang lain, dengan demikian dituntut adanya kemampuan guru dalam menguasai dan menerapkan berbagai macam metode pembelajaran. Semakin baik metode itu, makin efektif pula pencapaian tujuan. (Djamarah dan Zain, 2010) menyebutkan bahwa kedudukan metode adalah sebagai alat motivasi ekstrinsik, sebagai strategi pengajaran dan juga sebagai alat untuk mencapai tujuan. (Faturrohman, Pupuh dan Sobry, 2010) berpendapat makin tepat metode yang digunakan oleh guru dalam mengajar, diharapkan makin efektif pula pencapaian tujuan pembelajaran.

Berdasarkan pendapat di atas jelaslah bahwa metode pembelajaran dapat membantu pendidik untuk mencapai tujuan pendidikan yang telah ditetapkan. Dan metode yang dilaksanakan mestilah dapat menimbulkan kemauan peserta didik untuk mencapai tujuan pendidikan dengan efektif dan efisien.

Motivasi sangat penting bagi seseorang untuk melakukan sesuatu karena dengan adanya motivasi akan bersemangat untuk mendapatkan sesuatu yang diinginkan, sebab motivasi merupakan dorongan dari dalam diri untuk melakukan sesuatu. Motivasi belajar merupakan motor penggerak untuk mendorong peserta didik berbuat dan melakukan sesuatu, karena keinginan yang muncul dari dalam dirinya. (Koeswara, 1995) mengemukakan bahwa dalam disiplin ilmu psikologi, motivasi merupakan konsep yang digunakan untuk menerangkan kekuatan-kekuatan yang ada dan bekerja pada diri organisme atau individu yang menjadi penggerak dan pengarah tingkah laku individu tersebut. Para teoritikus motivasi dalam menyusun konsepsi teori mengenai motivasi bisa dikategorikan dalam tiga pendekatan yang utama, yakni: (1) pendekatan biologis, (2) pendekatan behavioristik, dan (3) pendekatan kognitif. Menurut (Winkel, 1991) motivasi belajar adalah keseluruhan daya penggerak psikis di dalam diri peserta didik yang menimbulkan kegiatan belajar, menjamin kelangsungan belajar, dan memberikan arah pada kegiatan belajar demi mencapai suatu tujuan. (Sardiman, 2012, p. 74) juga menyatakan bahwa motivasi akan menyebabkan terjadinya suatu perubahan energi yang ada pada diri manusia, sehingga akan bergayut dengan persoalan gejala kejiwaan, perasaan dan juga emosi, untuk kemudian bertindak atau melakukan sesuatu. (Nasar, 2006, p. 34) menjelaskan bahwa membuat siswa menyenangi kegiatan belajar adalah pondasi utama dalam mengerakkan peserta didik agar mampu mengatur pembelajarannya sendiri. Namun, perlu diingat, bahwa kesenangan siswa dalam belajar tercermin bukan dalam 
1811 Peningkatan Pembelajaran Pendidikan Agama Islam Melalui Model PAIKEM Bagi Siswa Sekolah Dasar-Repelita

DOI: https://doi.org/10.31004/basicedu.v5i4.989

kegaduhan canda tawa, tetapi dalam keasyikan dalam mengerjakan tugas belajar dan keinginan untuk terus menerus mengelaborasi pengetahuan/keterampilan yang sedang di pelajarinya (Joyfull Learning).

Melihat situasi dan kondisi dalam pelaksanaan pendidikan di SD pada saat ini, siswa dituntut untuk bersifat aktif dan kreatif. Siswa hendaknya menjadi objek utama dalam proses pembelajaran sedangkan guru hanya bertindak sebagai fasilitator. Salah satu model pembelajaran yang dapat digunakan untuk pembelajaran PAI di SD adalah model PAIKEM. Guru PAI memiliki peran yang sangat penting dalam menentukan kuantitas dan kualitas pembelajaran Pendidikan Agama Islam dengan menggunakan model PAIKEM. Guru PAI harus memikirkan dan membuat perencanaan secara seksama dalam meningkatkan kesempatan belajar bagi siswanya dan memperbaiki kualitas mengajarnya. Penerapkan model PAIKEM menuntut perubahan-perubahan dalam pengorganisasian kelas, penggunaan metode mengajar, strategi belajar-mengajar, maupun sikap dan karakteristik guru dalam mengelola proses belajar-mengajar. Menurut (Slameto, 2011), PAIKEM mengandung makna pembelajaran yang dirancang agar mengaktifkan anak, mengembangkan inovasi dan kreativitas sehingga efektif namun tetap menyenangkan. (Jauhar, 2011, p. 150), mengemukakan PAIKEM merupakan singkatan dari (Pembelajaran aktif, inovatif, kreatif, efektif dan menyenangkan). PAIKEM didefinisikan sebagai pendekatan (approach to teaching) yang digunakan bersama metode tertentu dan sebagai media pengajaran yang disertai penataan lingkungan sedemikian rupa agar proses pembelajaran menjadi aktif, inovatif, kreatif, efektif, dan menyenangkan. Dengan demikian, para siswa merasa tertarik dan mudah menyerap pengetahuan dan keterampilan yang diajarkan. Selain itu, PAIKEM juga memungkinkan siswa melakukan kegiatan yang beragam untuk mengembangkan sikap, pemahaman, dan keterampilannya sendiri dalam arti tidak semata-mata "disuapi" guru.

Menurut (Jauhar, 2011, p. 151) ada beberapa karakteristik PAIKEM yaitu : Berpusat pada siswa (studentcentered), belajar yang menyenangkan (joyfull learning), belajar yang beorientasi pada tercapainya kemampuan tertentu (competency-based learning), belajar secara tuntas (mastery learning), belajar secara berkesinambungan (continuous learning) dan belajar sesuai dengan ke-kini-an dan ke-disini-an (contextual learning).

Guru PAI berperan sebagai pengelola proses belajar-mengajar, bertindak selaku fasilitator yang berusaha menciptakan kondisi belajar-mengajar yang efektif sehingga memungkinkan proses belajar-mengajar, mengembangkan bahan pelajaran dengan baik, dan meningkatkan kemampuan siswa untuk menyimak pelajaran dan menguasai tujuan-tujuan pendidikan yang harus mereka capai. Agar hasil ini dapat optimal, guru dituntut untuk mengubah peran dan fungsinya menjadi fasilitator, mediator, mitra belajar anak didik, dan evaluator. Menurut (Quthub, n.d., p. 67) bahwa sesungguhnya, langkah yang memiliki pengaruh positif, itulah yang dikenal dengan pembelajaran efektif. Cara yang digunakan harus selaras dengan kemampuan anak didik. Di samping itu cara penyampaian materi harus bertahap dan menggunakan metode sesuai dengan materi. Agar semua itu dapat terwujud dengan efktif, maka seorang guru harus menggunakan pola pengajaran yang variatif. Model PAIKEM yang aktif dan kreatif tentunya lebih baik dilaksanakan apabila diiringi dengan pembelajaran yang inovatif.

Model PAIKEM membuat siswa selalu aktif dan kreatif, tentunya didukung dengan proses pembelajaran yang efektif, sehingga pembelajaran yang dilaksanakan menjadi bermakna. Hal ini pun harus ditunjang dengan proses pembelajaran yang menyenangkan sehingga siswa tertarik dan mau berkolaborasi dengan guru pada saat proses pembelajaran dilaksanakan. Hal ini juga dijelaskan dalam Firman Allah SWT, QS. An-Nahl ayat 125 yang terjemahannya sebagai berikut :

Artinya : Serulah (manusia) kepada jalan Tuhan-mu dengan hikmah dan pelajaran yang baik. (Q.S An-Nahl ayat 125)

Dengan ayat di atas jelas bagi kita bahwa untuk mencapai hasil yang lebih baik hendaklah seorang pendidik menggunakan strategi dan metode yang sesuai dengan situasi dan kondisi yang ada. Sehingga peserta didik menerima pembelajaran dengan menyenangkan dan tergugah hatinya untuk melaksanakan ajaran agama 
1812 Peningkatan Pembelajaran Pendidikan Agama Islam Melalui Model PAIKEM Bagi Siswa Sekolah Dasar-Repelita

DOI: https://doi.org/10.31004/basicedu.v5i4.989

Islam dalam kehidupan. Pembinaan agama membutuhkan pada sentuhan rohani dan dorongan dari dalam diri. Bila jiwa menerima rangsangan yang menarik dan menyenangkan, maka anggota badan atau jasmani akan tergerak untuk melakukan hal yang diharapkan.

Proses belajar mengajar belum sesuai dengan yang diharapkan bila hanya menggunakan metode ceramah dan tanya jawab saja..Hal ini dapat dilihat dari proses belajar mengajar, dimana siswa tidak termotivasi dalam melaksanakan proses pembelajaran dengan baik dan menyenangkan. Dalam proses pembelajaran siswa lebih banyak bermain dan sebagiannnya merasa kurang betah untuk mengikuti pembelajaran dan tidak berkonsentrasi dalam melaksanakan proses pembelajaran. Permasalahan ini terjadi karena proses pembelajarn yang dilakukan hanya melalui metoda ceramah dan tanya jawab saja. Proses pembelajaran Pendidikan Agama Islam juga dituntut agar siswa menemukan inti dalam proses pembelajaran itu sendiri. Salah satu model pembelajaran yang dapat dilaksanakan ialah melalui model PAIKEM yang membuat siswa selalu aktif dan kreatif sekaligus menimbulkan kegembiraan bagi siswa dalam pembelajaran. Model pembelaran ini cocok dilakukan untuk menimbulkan minat dan semangat peserta didik.

(Ismail SM, 2008, p. 84) mengemukakan langkah dalam PAIKEM yang dapat digunakan dalam pembelajaran PAI di SD adalah "Setiap murid sebagai guru". Yang langkah-langkah penerapannya sebagai berikut: Bagikan kertas kepada setiap siswa dan mintalah mereka untuk menuliskan sebuah pertanyaan tentang materi pokok yang telah atau sedang dipelajari, atau topik khusus yang ingin mereka diskusikan. Kumpulkan kertas-kertas tersebut, dikocok dan dibagikan kembali secara acak dan diusahakan pertanyaan tidak kembali pada yang bersangkutan. Mintalah mereka membaca dan memahami pertanyaan, Undang sukarelawan untuk membacakan pertanyaan yang ada di tangannya tanpa menunjuknya.Mintalah dia memberikan respons (jawaban/penjelasan) atau pertanyaan atau permasalahan tersebut kemudian mintalah kepada temannya untuk memberi pendapat. Berikan apresiasi terhadap setiap jawaban/tanggapan. Kembangkan diskusi dengan cara bergantian membacakan pertanyaan. Guru melakukan kesimpulan, klarifikasi dan tindak lanjut.

Dalam proses pembelajaran seperti yang dikemukakan oleh Ismail di atas, dapat disimpulkan bahwa model ini dilaksanakan untuk mengasah keterampilan siswa dalam proses pembelajaran. Sehingga siswalah yang aktif dan guru hanya bertindak sebagai fasilitator. Yang mengarahkan siswa selama proses pembelajaran. Tentunya ada peraturan yang diberikan guru selama proses pembelajaran berlansung sehingga suasana kelas bisa berjalan dengan kondusif selama proses pembelajaran.

Dalam rangka mencapai hal tersebut dibutuhkan kemauan dan kebijakan guru dalam mencapai tujuan pendidikan yang diharapkan. Hal ini sesuai dengan firman Allah dalam surat Ar-ra'du ayat 11, yang artinya :

Artinya: "Sesungguhnya Allah SWT tidak merubah keadaan suatu kaum sehingga mereka merubah keadaan yang ada pada diri mereka sendir. (QS. Ar-ra'du :11)

Ayat di atas menjelaskan bahwa jika kita ingin suatu perobahan dan peningkatan ke arah yang lebih baik, membutuhkan adanya suatu usaha dan kemauan untuk mencoba dan memulainya. Sehingga akan mendatangkan hasil yang diinginkan. Keinginan tanpa ada perobahan yang dilakukan akan sisa-sia belaka. Tapi keinginan yang diikuti dengan perobahan dan semangat kerja yang ikhlas, insya Allah cita-cita akan dapat terwujud.

Berdasarkan uraian di atas penulis terdorong untuk mengkaji bagaimana pengaruh Model Pembelajaran PAIKEM terhadap Peningkatan Pembelajaran Pendidikan Agama Islam di sekolah dasar. Yang mengkaji tentang bagaimana peningkatan pembelajaran PAI melalui model PAIKEM bagi siswa sekolah dasar negeri 07 Pasaman Kabupaten Pasaman Barat.

Secara umum, penelitian ini bertujuan untuk mendeskripsikan tentang proses berlansungnya peningkatan pembelajaran PAI melalui model PAIKEM bagi siswa kelas V sekolah dasar negeri 07 Pasaman. Secara khusus, penelitian ini bertujuan untuk : Mendeskripsikan rancangan pembelajaran peningkatan pembelajaran PAI melalui model PAIKEM, mendeskripsikan pelaksanaan peningkatan pembelajaran PAI melalui model 
1813 Peningkatan Pembelajaran Pendidikan Agama Islam Melalui Model PAIKEM Bagi Siswa Sekolah Dasar-Repelita

DOI: https://doi.org/10.31004/basicedu.v5i4.989

PAIKEM dan mendeskripsikan peningkatan hasil penilaian pembelajaran PAI melalui model PAIKEM bagi siswa kelas V sekolah dasar negeri 07 Pasaman.

Secara teoritis, hasil penelitian ini untuk dapat mengingatkan kembali dan diharapkan dapat memberikan sumbangan bagi Pendidikan Agama Islam di semua tingkat sekolah, khususnya pendidikan sekolah dasar. Model PAIKEM diharapkan juga dapat memberi semangat untuk mengadakan perobahan dalam melaksanakan proses pembelajaran. Bukan saja pada mata pelajaran PAI, tapi juga untuk seluruh mata pelajaran. Agar dapat meningkatkan hasil belajar peserta didik dan tergerak hatinya untuk melaksanakan ilmu pengetahuan dalam kehidupan.

\section{METODE PENELITIAN}

Subjek penelitian tindakan kelas ini adalah peserta didik kels V Sekolah Dasar Negeri 07 Pasaman, Kabupaten Pasaman barat dengan jumlah peserta 28 orang, yang terdiri dari 18 orang laki-laki dan 10 orang perempuan. Metode yang digunakan dalam penelitian ini ialah wawancara, observasi dan dokumentasi. Pendekatan yang peneliti gunakan adalah pendekatan kualitatif, karena peneliti ingin melihat situasi pembelajaran yang terjadi di lapangan. Dimana model PAIKEM sebagai bentuk model pembelajaran masih kurang digunakan oleh para guru Pendidikan Agama Islam, karena lebih sering menggunakan metoda ceramah dan tanya jawab. Penelitian ini berkenaan dengan perbaikan atau peningkatan proses pembelajaran pada suatu kelas.

Kegiatan itu dimulai dengan merumuskan rancangan tindakan pembelajaran, dengan kegiatan yaitu : Menyusun rancangan tindakan, Menyusun indikator dan kriteria pembelajaran dengan menerapkan konsep model PAIKEM. Menyusun alat perekam data berupa pedoman observasi, pedoman wawancara, catatan lapangan dan dokumentasi. Melakukan Wawancara dengan observer untuk membuat perencanaan, melaksanakan dan mengevaluasi pembelajaran melalui model PAIKEM .

Penelitian ini dilaksanakan dalam dua siklus. Setiap siklus dilaksanakan satu kali pertemuan sesuai dengan rencana pembelajaran yang telah disusun. Kegiatan dilakukan oleh penulis sebagai peneliti dan teman sejawat yang bertindak sebagai observer. Pengamatan terhadap tindakan pembelajaran PAI melalui model PAIKEM dilakukan bersamaan dengan pelaksanaan tindakan. Hal ini dilaksanakan secara intensif, objektif dan sistematis. Pengamatan dilakukan oleh observer pada waktu penulis melaksanakan tindakan pembelajaran PAI.

Data penelitian ini berupa hasil pengamatan, dan dokumentasi dari setiap tindakan peningkatan pembelajaran PAI melalui model PAIKEM. Data tersebut tentang hal-hal yang berkaitan dengan perencanan, pelaksanaan, dan hasil pembelajaran. Baik dari pihak guru maupun dari siswa.. Catatan lapangan berisi deskripsi tentang pengamatan terhadap tindakan peneliti sewaktu proses pembelajaran. Wawancara digunakan untuk memperkuat data obsevasi yang terjadi dalam kelas. Tes dilaksanakan untuk memperkuat data observasi yang terjadi di dalam kelas dalam butir penguasaan materi pembelajaran dari unsur siswa. Instrumen untuk penelitian adalah penulis, observer dan peroses pembelajaran yang berlangsung.

Data yang diperoleh dalam penelitian dianalisis dengan menggunakan Model Analisa Data Kuantitatif dan kualitatif yakni analisis data dimulai dengan menelaah sejak penggumpulan data sampai seluruh data terkumpul. Data tersebut direduksi berdasarkan masalah yang diteliti. Diikuti penyajian data dan terakhir penyimpangan atau verifikasi.. Analisis data dilakukan terhadap data yang telah direduksi baik data perencanaan, pelaksanaan, maupun data evaluasi.

\section{HASIL DAN PEMBAHASAN}

Sebelum penelitian ini dilaksanakan, pembelajaran Pendidikan Agama Islam dilaksanakan dengan pembelajaran tradisional. Pembelajaran hanya bersifat monoton, guru menyampaikan materi pelajaran deng an ceramah dan tanya jawab saja, peserta didik cenderung mendengarkan sehingga peserta didik akan bosan dan tidak tertarik dalam mengikuti pembelajaran.. Selain itu, prestasi belajar peserta didik akan cenderung rendah 
1814 Peningkatan Pembelajaran Pendidikan Agama Islam Melalui Model PAIKEM Bagi Siswa Sekolah Dasar-Repelita

DOI: https://doi.org/10.31004/basicedu.v5i4.989

dan tidak memuaskan. Hal tersebut dapat dilihat dari hasil prestasi belajar Pendidikan agama Islam pada setiap memberikan Penilaian Harian, Penilaian Tengah Semester dan Penilaian Akhir Semeter.

Proses pembelajaran yang dilaksanakan dimulai dengan merancang rencana pelaksanaan pembelajaran dengan sebaik mungkin. Dengan memilih metode, alat bantu yang sesuai serta sumber belajar dengan memperhatikan prinsip-prinsip pembelajaran model PAIKEM. Penyajian pembelajaran yang dilakukan kali ini diusahakan dengan menggunakan metoda yang bervariasi, sehingga proses pembelajaran menjadi menarik oleh siswa. Pelaksanaan proses pembelajaran terdiri atas tiga tahapan yaitu: (1) kegiatan awal, (2) kegiatan inti, dan (3) kegiatan akhir.

Pelaksanaan peningkatan pembelajaran PAI melalui model PAIKEM bagi siswa pada siklus I berlangsung dalam 3 kegiatan yaitu. Kegiatan awal, kegiatan inti dan kegiatan akhir. Kegiatan awal dimulai oleh guru dengan menyiapkan kondisi kelas dengan sebaik-baiknya. Proses pembelajaran baru bisa dimulai apabila siswa telah duduk dengan rapi dan sudah siap menerima pelajaran dari guru. Hal ini sangat penting dilakukan agar siswa berkonsentrasi dalam proses pembelajaran. Selanjutnya siswa berdoa yang dipimpin oleh ketua kelas. Hal selanjutnya yang penulis lakukan adalah menyampaikan tujuan pembelajaran kepada siswa. Ada sebagian dari siswa yang antusias mendengar tujuan pembelajaran ini ada sebagian yang kurang begitu tertarik. Namun ketika guru memulainya dengan nyanyi yang berhubungan dengan materi, seluruh siswa memperlihatkan ketertarikannya.. Kemudian diselingi dengan tepuk PPK, siswa lebih berminat lagi dalam proses pembelajaran di depan kelas sehingga proses pembelajaran menjadi menyenangkan seperti yang diharapkan dalam model PAIKEM.

Kegiatan selanjutnya adalah kegiatan inti, guru meminta siswa membaca materi dalam buku paket PAI. Guru meminta siswa membaca materi secara hati-hati agar memahaminya dengan baik selama 10 menit. Hal selanjutnya yang dilakukan guru adalah membagikan kertas pertanyaan kepada siswa. Kertas pertanyaan yang diberikan guru adalah kertas tempat siswa menuliskan satu pertanyaan mengenai materi tersebut. Tetapi pada kolom jawaban guru belum memperbolehkan siswa untuk menuliskan jawaban karena akan ditulis jawabannya oleh teman yang lainnya. Setelah siswa selesai menuliskan pertanyaan, guru meminta siswa mengumpulkan semua pertanyan tersebut. Setelah semua pertanyaan terkumpul guru membagikan kepada setiap siswa kembali. Tetapi siswa yang menerima pertanyaan bukanlah yang menulisnya melainkan temannya yang lain.

Setiap siswa tidak mendapat pertanyaan yang sama. Setelah semua pertanyaan diterima oleh siswa maka guru meminta siswa menuliskan jawaban pertanyaan tersebut dengan sebaik-baiknya. Setelah siswa selesai menuliskan jawaban maka guru meminta siswa menjawab pertanyaan yang ada padanya secara spontan. Berbeda dengan menjawab pertanyaan biasa siswa diminta menerangkan jawaban yang telah ditulisnya seperti seorang guru yang menerangkan, dengan cara berdiri di tempat duduknya masing-masing. Siswa kelihatan begitu antusias dalam memberikan jawaban atas pertanyaan yang sebelumnya ditulis oleh temannya tentang materi tersebut. Sembari siswa menjawab pertanyaan yang ada padanya. Guru memberikan respon kepada siswa berupa pujian.

Guru mengembangkan diskusi sehingga dengan cara mengajukan beberapa pertanyaan kembali sehingga siswa mampu menjawab pertanyaan yang berhubungan dengan materi. Terakhir pada kegiatan inti siswa menyampaikan hasil diskusinya. Guru juga senang dengan cara siswa menyampaikan hasil diskusinya dengan percaya diri dan berani. Kegiatan akhir adalah siswa dibawah bimbingan guru menyimpulkan pembelajaran yang dilaksanakan. Lalu guru melaksanakan evaluasi terhadap proses pembelajaran yang dilaksanakan sejauh mana keberhasilan model PAIKEM ini dilaksanakan dalam peningkatan pembelajaran PAI tentunya dibantu oleh observer. Terakhir guru memberikan tindak lanjut kepada siswa dengan memberikan tugas menyebutkan contoh perbuatan sehari-hari yang sesuai dengan materi. Tujuannya agar siswa lebih memahami materi. 
1815 Peningkatan Pembelajaran Pendidikan Agama Islam Melalui Model PAIKEM Bagi Siswa Sekolah Dasar-Repelita

DOI: https://doi.org/10.31004/basicedu.v5i4.989

Tabel 1

Perbandingan Perolehan Hasil Peningkatan Pembelajaran PAI Melalui Model PAIKEM Bagi Siswa Kelas V Sekolah Dasar Negeri 07 Pasaman Sebelum Tindakan Dengan Pelaksanaan pada Siklus 1

\begin{tabular}{|c|c|c|}
\hline \multirow{2}{*}{ No } & \multicolumn{2}{|c|}{ Perbandingan } \\
\hline & $(\mathbf{X})$ & $(\mathbf{Y})$ \\
\hline 1. & 85,5 & 95,5 \\
\hline 2. & 70 & 73 \\
\hline 3. & 60 & 69 \\
\hline 4. & 68,5 & 73,5 \\
\hline 5. & 65 & 72,5 \\
\hline 6. & 70 & 81,5 \\
\hline 7. & 70 & 73,5 \\
\hline 8. & 68 & 72,5 \\
\hline 9. & 65 & 68,5 \\
\hline 10. & 72,5 & 82 \\
\hline 11. & 67,5 & 71 \\
\hline 12. & 50 & 61 \\
\hline 13. & 70 & 71 \\
\hline 14. & 75 & 83 \\
\hline 15. & 67,5 & 70,5 \\
\hline 16. & 75 & 84,5 \\
\hline 17. & 60 & 61,5 \\
\hline 18. & 75 & 83,5 \\
\hline 19. & 67 & 71 \\
\hline 20. & 85 & 87 \\
\hline 21. & 75 & 84 \\
\hline 22. & 85 & 87,5 \\
\hline 23. & 83,5 & 86 \\
\hline 24. & 60 & 70,5 \\
\hline 25. & 65 & 72 \\
\hline 26. & 50 & 60 \\
\hline 27. & 65 & 70 \\
\hline 28. & 50 & 65 \\
\hline JUMLAH & 1920 & 2105,5 \\
\hline $\begin{array}{l}\text { RATA- } \\
\text { RATA }\end{array}$ & 68,6 & 75,2 \\
\hline
\end{tabular}

Keterangan:

1. Nilai siswa kelompok $X$ yaitu kelompok siswa yang tidak mengunakan model pembelajaran PAIKEM

2. Nilai siswa kelompok Y : Yaitu kelompok siswa yang diberi tindakan berupa pengajaran dengan menggunakan model PAIKEM.

3. Persentase ketuntasan siswa :

Kelompok X Siswa yang tuntas

Kelompok Y Siswa yang tuntas

: 4 orang, Persentase ketuntasan

: 10 orang, Persentase ketuntasan

$$
:(4: 28) \times 100=14 \%
$$$$
:(10: 28) \times 100=36 \%
$$

Dari hasil tersebut tampak nilai uji siswa kelompok Y lebih baik dibandingkkan dengan siswa kelompok X. 28 orang siswa di kelompok X, hanya 4 orang yang mencapai nilai diatas 76 sesuai kriteria ketuntasan sekolah yang ditetapkan. Sehingga hanya $14 \%$ siswa yang tuntas.Sedangkan dikelompok Y ada 10 orang Siswa yang mencapai KKM. Ketuntasan kelas meningkat mencapai 36\%. Pada penilaian hasil di siklus 1 , baru 10 siswa yang mencapai ketuntasan, dimana 10 orang siswa ini memperoleh nilai di atas 76 dan selebihnya memperoleh nilai dibawah 76 yang tentunya ini menjadi catatan tersendiri oleh guru apakah siswa 
masih ada yang bermain-main dalam proses pembelajaran, Walaupun rata-rata nilai yang diperoleh sudah mencapai 75,2 yang berada pada taraf hampir baik, tentunya tetap menjadi beban bagi guru karena 18 orang dari 28 orang siswa belum mencapai ketuntasan.

Pelaksanaan peningkatan pembelajaran PAI melalui model PAIKEM bagi siswa Sekolah Dasar Negeri 07 Pasaman pada siklus II,berlangsung dalam 3 kegiatan yaitu. Kegiatan awal, kegiatan inti dan kegiatan akhir. Kegiatan awal dimulai dengan menyiapkan kondisi kelas dengan sebaik-baiknya. Siswa yang pada siklus I sudah dalam keadaan rapi duduknya kini semakin disipilin dalam menyiapkan kondisi kelas. Wajah mereka yang berseri-seri tampak menunjukkan keinginan mereka untuk belajar dengan baik. Selanjutnya guru menyampaikan tujuan pembelajaran, dan kembali dengan nyanyi sesuai materi serta tepuk semangat dan tepuk PPK. Ada yang menarik pada saat tepuk semangat dan tepuk PPK sebagian besar murid menampakkan kesenangannya dengan belajar. Kegiatan selanjutnya adalah kegiatan inti. Guru kembali menugaskan siswa untuk membaca materi di buku paketnya. Siswa membaca materi dengan hati-hati kembali. Siswa kelihatan serius saat membaca bukunya. Tidak terdengar suara gaduh seperti yang ada ada siklus I. Selanjutnya guru membagikan kertas pertanyaan kepada siswa. Agar suasana belajar menjadi kondusif, guru membagikan kertas dengan memanggil bergiliran lima orang ke depan kelas sampai siswa yang terakhir. Setelah kertas pertanyaan dibagikan guru meminta siswa menuliskan satu pertanyaan tentang materi. Ada hal yang menarik pada siklus I , siswa kelihatan ragu-ragu dalam menuliskan pertanyaan, tetapi pada siklus II ini, ada sebagian dari siswa yang mempersiapkan pertanyaan dari rumah. Sehingga mereka tidak kesulitan saat menuliskan pertanyaan tentang materi. Guru meminta kertas pertanyaan yang telah ditulis oleh seluruh siswa. Agar tidak terjadi kericuhan seperti siklus I guru memanggil setiap siswa ke depan kelas secara bergiliran untuk menerima pertanyaan yang ditulis temannya, dan memastikan pertanyaan tersebut tidak kembali kepada yang menulisnya. Setelah semua kertas pertanyaan diberikan guru meminta semua siswa memahami semua pertanyaan yang telah ditulis temannya. Siswa menuliskan jawaban yang telah disediakan dalam kolom jawaban.

Siswa dengan cepat menuliskan jawaban, selanjutnya guru ke depan mencontohkan bagaimana menjawab pertanyaan dan mencontohkan bagaimana cara menerangkan di depan kelas seperti seorang guru. Ada beberapa orang yang langsung ke depan kelas untuk memberikan jawaban. Tetapi guru menegaskan setiap siswa ke depan kelas diberikan waktu 1,5 menit sehingga proses pembelajaran bisa berjalan dengan efektif. Guru memanggil dan mengundang siswa ke depan kelas untuk menjawab sekaligus menerangkan jawaban yang telah ditulisnya. Siswa mampu menerangkan jawaban sebagaimana guru yang sedang menerangkan pelajaran di depan kelas. Sungguh hal ini adalah hal yang sangat membanggakan sekali. Siswa yang dulunya malu-malu untuk ke depan kelas kini telah mampu memahami materi dengan baik. Setelah semua siswa tampil memberikan jawabannya guru memberikan pujian kepada siswa karena telah mampu menjelaskan materi dengan baik.. Selanjutnya guru kembali melanjutkan diskusi untuk memantapkan konsep materi tersebut. Hal penting yang dapat dipetik dalam kegiatan ini adalah siswa sudah mampu menyebutkan contoh sesuai materi, Sehingga ketika menyampaikan hasil diskusinya ke depan kelas, siswa tidak canggung lagi. Kegiatan akhir dilaksanakan dengan menyimpulkan pembelajaran di bawah bimbingan guru, selanjutnya guru melaksanakan evaluasi dengan jalan memberikan latihan. Terakhir memberikan tindak lanjut berupa pemberian pekerjaan rumah dengan memberikan soal-soal.

Tabel 2

Perbandingan Perolehan Hasil Peningkatan Pembelajaran PAI Melalui Model PAIKEM Bagi Siswa Sekolah Dasar Negeri 07 Pasaman sebelum Tindakan dengan Siklus I dan Siklus II

\begin{tabular}{c|c|c|c}
\hline \multirow{2}{*}{ No } & \multicolumn{3}{|c}{ Perbandingan } \\
\cline { 2 - 4 } & Sebelum Tindakan & Siklus I & Siklus II \\
\hline 1. & 85,5 & 95,5 & 96 \\
\hline 2. & 70 & 73 & 86 \\
\hline 3. & 60 & 69 & 84 \\
\hline 4. & 68,5 & 73,5 & 85 \\
\hline 5. & 65 & 72,5 & 88,5 \\
\hline
\end{tabular}


1817 Peningkatan Pembelajaran Pendidikan Agama Islam Melalui Model PAIKEM Bagi Siswa Sekolah Dasar-Repelita

DOI: https://doi.org/10.31004/basicedu.v5i4.989

\begin{tabular}{c|c|c|c}
\hline 6. & 70 & 81,5 & 89 \\
\hline 7. & 70 & 73,5 & 82 \\
\hline 8. & 68 & 72,5 & 87 \\
\hline 9. & 65 & 68,5 & 83,5 \\
\hline 10. & 72,5 & 82 & 87,5 \\
\hline 11. & 67,5 & 71 & 73 \\
\hline 12. & 50 & 61 & 84,5 \\
\hline 13. & 70 & 71 & 73 \\
\hline 14. & 75 & 83 & 93,5 \\
\hline 15. & 67,5 & 70,5 & 86,5 \\
\hline 16. & 75 & 84,5 & 97 \\
\hline 17. & 60 & 61,5 & 81 \\
\hline 18. & 75 & 83,5 & 88,5 \\
\hline 19. & 67 & 71 & 74 \\
\hline 20. & 85 & 87 & 92 \\
\hline 21. & 75 & 84 & 89 \\
\hline 22. & 85 & 87,5 & 91,5 \\
\hline 23. & 83,5 & 86 & 91,5 \\
\hline 24. & 60 & 70,5 & 91,5 \\
\hline 25. & 65 & 72 & 91 \\
\hline 26. & 50 & 60 & 98 \\
\hline 27. & 65 & 70 & 89 \\
\hline 28. & 50 & 65 & 2442 \\
\hline Jumlah & 1920 & 2105,5 & 87,2 \\
\hline RATA- & 68,6 & 75,2 & \\
RATA & & & \\
\hline
\end{tabular}

Persentase ketuntasan siswa :

1. Sebelum Tindakan :

Siswa yang tuntas

2. Siklus 1

Siswa yang tuntas

3. Siklus 11

Siswa yang tuntas
: 4 orang, Persentase ketuntasan

: 10 orang Persentase ketuntasan

: 25 orang Persentase ketuntasan
$:(4: 28) \times 100=14 \%$

$:(10: 28) \times 100=36 \%$

$:(25: 28) \times 100=89 \%$

Dari tabel 2 mengenai hasil pelaksanaan pembelajaran PAI dapat dilihat pembelajaran sebelum tindakan yang tuntas hanya 4 orang, pada siklus 1 yang tuntas 10 orang dan hasil pembelajaran siswa sudah terjadi peningkatan. Pada siklus 2 yang tuntas sudah mencapai 25 orang. Rata-rata hasil uji siswa sebelum tindakan hanya 68,6, pada siklus 1 meningkat menjadi 75,2 dan pada siklus 2 mencapai 87,2.

Dari segi penilaian guru merasa sangat puas sekali karena memperoleh hasil meningkat dari sebelum melakukan tindakan. Sebelum tindakan siswa yang mendapat nilai tuntas hanya $14 \%$. Pada siklus 1 siswa yang tuntas mencapai $36 \%$. Dan pada siklus 2 , siswa telah mampu mencapai tuntas sebanyak $89 \%$. Secara klasikal hanya 3 orang siswa yang belum mencapai ketuntasan artinya hanya $11 \%$ siswa yang belum tuntas dan sisanya 25 orang atau $89 \%$ telah mencapai ketuntasan. Sehingga siklus II ini dapat dikatakan berhasil. Materi pembelajaran PAI dapat diserap siswa dengan baik melalui pembelajaran dengan model pembelajaran PAIKEM.

\section{KESIMPULAN}

Berdasarkan pengamatan dan penelitian yang telah dilakukan dapat disimpulkan bahwa Pembelajaran yang dilaksanakan dengan pendekatan model Paikem memberikan pengaruh yang cukup signifikan terhadap 
1818 Peningkatan Pembelajaran Pendidikan Agama Islam Melalui Model PAIKEM Bagi Siswa Sekolah Dasar-Repelita

DOI: https://doi.org/10.31004/basicedu.v5i4.989

proses belajar siswa. Hal ini dapat dilihat dari proses dan hasil belajar siswa.Siswa menjadi bersemangat dalam belajar dan dalam situasi yang menyenangkan. Peningkatan tersebut dapat telihat dalam uji kemampuan awal dan akhir siswa dalam mengerjakan tugas. Siswa mulanya punya kemampuan biasa saja dan dibawah ketuntasan, akhirnya setelah diberikan tindakan mengalami peningkatan baik dari aspek pengetahuan, sikap maupun keterampilan dalam proses pembelajaran.

Disamping itu, siswa juga terlihat semakin aktif, termotivasi dalam belajar jika diajarkan dengan pendekatan model PAIKEM. Saran yang dapat diberikan kepada guru hendaknya dapat menerapkan strategi, model, dan pendekatan yang lebih bervariasi dalam Pembelajaran, agar siswa lebih antusias dalam belajar.

\section{UCAPAN TERIMA KASIH}

Selanjutnya, Terima kasih diucapkan kepada yang turut serta membantu penulisan artikel dan kepada seluruh tim jurnal basicedu yang telah membantu dalam penerbitan artikel ini.

\section{DAFTAR PUSTAKA}

Djamarah, S.B dan Zain, A. (2010). Strategi Belajar Mengajar. Jakarta: Rineka Cipta.

Faturrohman, Pupuh dan Sobry, M. (2010). Strategi Belajar Mengajar melalui Penanaman Konsep Umum \& Konsep Islami. Bandung : Refika Aditama.

Ismail SM. (2008). Strategi Pembelajaran Agama Islam Berbasis PAIKEM. Semarang: Rasail.

Jauhar, M. (2011). Implementasi PAIKEM dari Behavioristik sampai Konstruktivistik. Jakarta: Prestasi Pustaka. Koeswara. (1995). Motivasi: Teori dan Penelitian. Bandung: Angkasa.

Mulyono, A. (2003). Pendidikan bagi Anak Berkesulitan Belajar. Jakarta: Rineka Cipta.

Nasar. (2006). Merancang Pembelajaran Aktif dan Kontekstual Berdasarkan Sisko. Jakarta: Rasindo.

Quthub, U. dan M. K. (n.d.). Menjadi Guru yang Dirindu. Surakarta: Ziyad Books.

Saepul Rahmat, A. (2015). Pengaruh Metode Pembelajaran Inkuiri terhadap Hasil Belajar Siswa tentang Lingkungan Alam dan Buatan. Jurnal Pedadidaktika, 2(2).

Sardiman, A. (2012). Interaksi dan Motivasi Belajar Mengajar. Jakarta: Raja Grafindo Persada.

Slameto. (2011). Model PEIKEM. Semarang: UNNES.

Sudjana. (1992). Metode Statistika. Bandung:Tarsito.

Surakhmad, W. (1990). Pengantar Penelitian Ilmiah: Dasar, Metode, dan Teknik. Bandung:Tarsito.

Susanto, A. (2014). Teori Belajar dan Pembelajaran di Sekolah Dasar. Jakarta: Kencana Prenada Media Group. Uno, H. B. (2012). Belajar Dengan Pendekatan PAIKEM. Jakarta: Bumi Aksara.

Winkel, W. (1991). Psikologi Pengajaran. Jakarta: Grasindo. 